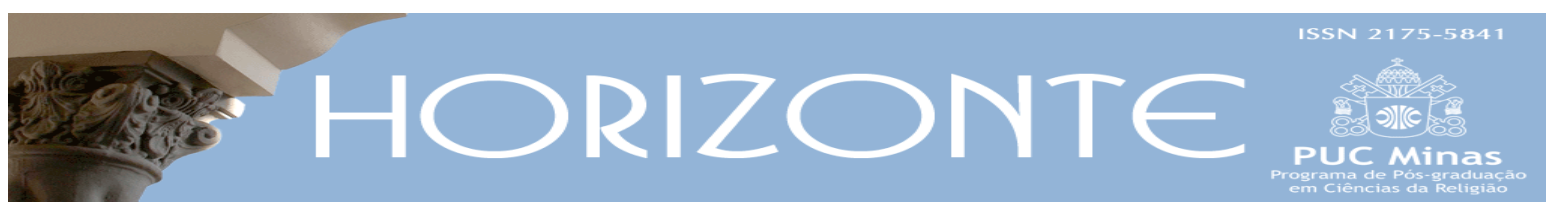

Dossiê: Conferência de Puebla: 40 anos - Artigo original (c) (i)

\title{
A teologia de Puebla: lutas, ambiguidades e continuidades
}

\author{
The theology of Puebla: fights, ambiguities and continuities
}

\author{
João Décio Passos*
}

\begin{abstract}
Resumo
A reflexão sobre a teologia de Puebla expõe duas tendências teológicas presentes na assembleia e no documento final. A primeira tendência de matriz clássica descansa sobre uma visão essencialista da realidade. A segunda se estrutura a partir da historicidade e tem sua elaboração final na categoria sinais dos tempos, consagrada pelo Concílio. A luta teológica tece como resultado o texto conclusivo de Puebla e expressa a luta pelo sentido do Vaticano II. Não obstante, essa luta hermenêutica, a recepção da III Conferência acontecerá em uma perspectiva histórica e libertadora em continuidade com a tradição consolidada da Conferência de Medellín. O contexto histórico atual constitui um pressuposto que reafirma a atualidade dos ensinamentos de Puebla. A reflexão parte das possibilidades históricas de realização de Puebla, verifica a luta interna pelos sentidos do Vaticano II e de Medellín ocorridas no interior do processo e conclui com a exposição das recepções da Conferência.
\end{abstract}

Palavras-chave: América Latina. CELAM. Episcopado. Igreja. Puebla. Teologia.

\begin{abstract}
The reflection on the theology of Puebla exposes two theological tendencies present in the assembly and in the final document. The first tendency of a classical matrix rests on an essentialist view of reality. The second is structured from the historicity and has its final elaboration in the category signs of the times, consecrated by the Council. The theological batlle results in the conclusive text of Puebla and expresses the batlle for the meaning of Vatican II. Nevertheless, this hermeneutic batlle, the reception of the Third Conference will take place in a historical and liberating perspective in continuity with the consolidated tradition of the Medellin Conference. The current historical context is a presupposition that reaffirms the current relevance of the teachings of Puebla. The reflection starts from the historical possibilities of Puebla's realization, verifies the internal struggle for the meanings of Vatican II and Medellín that occurred within the process and concludes with the presentation of the Conference receptions.
\end{abstract}

Keywords: Latin America. CELAM. Episcopacy. Church. Puebla. Theology.

Artigo submetido em 30 de maio de 2019 e aprovado em 22 de dezembro de 2019.

*Professor Livre-docente em Teologia pela PUC-SP.Professor da PUC-SP.País de origem: Brasil. E-mail: jdpassos@pucsp.br 


\section{Introdução}

A questão teológica em Puebla é multifacetada e complexa, tanto quanto o próprio evento. O texto final de Puebla (DP), de modo mais flagrante que em outros da mesma natureza, revela a luta entre dois projetos eclesiais originados de duas leituras distintas do Vaticano II e, por conseguinte, a presença dois modelos teológicos principais que operam como fundamentação dos debates, das decisões e do texto final. Diferentemente do documento de Medellín que possui um eixo teológico que conduz as reflexões das partes e do todo, seguindo de modo coerente os passos do método ver-julgar-agir e sustentando-se sobre uma perspectiva libertadora, o DP deixa transparecer a pluralidade de posições teológicas, os paralelismos de visões e as costuras de fragmentos de ideias e até de textos. Essa fragmentação real é aparentemente suplantada pelo estilo textual uniforme do documento final. O texto final está enquadrado em uma estrutura lógica que faz prevalecer uma forma esquemática geral, uma sequência lógica regular e uma clareza didática no modo de exposição que pode oferecer uma aparente coerência teórica (teológica) de fundo. Contudo, fica nítido no texto o esforço redacional que visa, por um lado, recolher o dissenso das posições presentes na assembleia e, por outro, construir um todo coerente.

As conclusões da III conferência são fruto de um contexto e de um processo, onde tendências teológicas predominam e, ainda, são resultadas de consensos construídos em uma assembleia, na qual a diversidade se faz presente necessariamente e o jogo dialético do debate conduz, de algum modo, os processos de reflexão e decisão. Por certo, pode-se formular com mais precisão uma primeira hipótese de análise: o DP, embora intencione uma unidade teológica, possui, na verdade, uma pluralidade de modelos teológicos passíveis de tipificação em alguns modelos principais que operam na forma e no conteúdo no conjunto e nas partes do texto. Nesse sentido técnico-metodológico, não há uma síntese teológica em Puebla, mas, antes, um encontro de visões ou modelos teológicos que se encontram e buscam responder a questões de fundo anteriores e persistentes 
durante as reflexões que construíram a Conferência possível. De fato, nenhum documento eclesial se faz com uma única teologia, o que, na prática, o tornaria politicamente inviável em uma assembleia inevitavelmente plural, ainda mais na era pós-conciliar. O DP, além do mais, se insere em um processo histórico-eclesial um antes, um durante e um depois - que lhe ancora em contextos distintos e em teologias distintas, a começar pela teologia que já se apresentava hegemônica no continente, a teologia da libertação. Ainda que na intencionalidade dos gestores da Conferência ligados a uma ortodoxia eclesial, com seu epicentro ativo na Cúria romana, tenha sido construir uma unidade teológica revisora dos rumos eclesiais latino-americano, uma assembleia eclesial se define precisamente pela busca de consenso e, por conseguinte, por um real dissenso. Nesse sentido, uma segunda hipótese busca precisar essa diversidade teológica que negocia e instaura um ecletismo estrutural nas conclusões da III Conferência: o DP expressa uma luta por hegemonia teológica que legitima duas perspectivas justapostas e em negociação: uma teologia clássica que predomina oficialmente e cumpre a função de garantir a ortodoxia doutrinal e uma teologia renovada que vincula a reflexão ao contexto histórico. Essa luta tem no fundo duas perspectivas teológicas, mas antes, duas cosmovisões com seus métodos decorrentes: uma visão essencialista e uma visão histórica.

Para além do texto oficial de Puebla é necessário buscar também o sentido que foi construído sobre a Conferência, quando do processo concreto de recepção. Essa hipótese afirma a função hermenêutica da recepção de Puebla na linha da continuidade com a tradição constituída de Medellín. É nesse processo que as orientações da III Conferência são praticadas/interpretadas pelos sujeitos eclesiais concretos, portanto onde a relação entre a objetividade do texto e sujeitos intérpretes ocorre e faz brotar um sentido global para aquelas orientações. A sensibilidade, a percepção e o compromisso com para com a história triunfaram no processo que tem a III Conferência como epicentro e marco eclesial na era pósconciliar na América Latina. 


\section{Possibilidades e limites político-hermenêuticos da III Conferência}

O método adotado pela Conferência de Puebla, caminho escolhido para atingir uma meta estabelecida por personagens gestores dos trabalhos, explica o resultado final formulado nas Conclusões e editado como documento oficial. A III Conferência foi realizada em torno da produção de um texto que deveria expressar de modo inequívoco um posicionamento claro do episcopado em relação ao momento histórico-eclesial vivenciado pelas Igrejas da América Latina e Caribe. Esse foi o objetivo assumido, defendido e operacionalizado por aqueles que se apresentaram como dirigentes investidos de uma legitimidade oficial delegada por Roma. ${ }^{1}$ É nessa condição de legitimidade que esses sujeitos conseguiram impor um determinado método para a execução da III Conferência, não obstante contassem com um sujeito eclesial autóctone defensor de outra perspectiva eclesial: seja parte da direção do CELAM e um número significativo dos delegados do episcopado local. A esse respeito vale recordar a expectativa temerosa do bispo Pedro Casaldáliga às vésperas da Conferência, no final do ano de 1978: "Pelo que vejo e leio, pelo que ouço de outros colegas e de muitos que pensam a América Latina e sua Igreja e as amam, eu tenho uma impressão negativa do CELAM. As grandes figuras do CELAM viram passar sua hora”. (CASALDÁLIGA, 1978, p. 585). E lamenta que a entidade havia assumido a posição de força de controle, uma espécie de Sagrada Congregação, deixando de ser uma "força de colegialidade do episcopado da Igreja da América Latina". No mesmo depoimento diz: "temos nossas reservas com respeito à gestão do atual secretário López Trujillo [...] dá a impressão que se sente com a missão - apoiado evidentemente por certas áreas vaticanistas - de polir Medellín, de dourar Medellín [...]. A gente, em todo caso, sente medo de que a próxima Conferência Episcopal de Puebla pudesse ser a Conferência do staff López Trujillo.” (CASALDÁLIGA, 1978, p. 585-586).

\footnotetext{
${ }^{1}$ O Papa Paulo VI nomeou presidentes da III Conferência, o Cardeal Sebastiano Baggio, prefeito da Congregação para os bispos e presidente da Comissão para a América Latina, Cardeal Aloísio Lorscheider, arcebispo de Fortaleza e presidente do CELAM e Dom Ernesto Corripio Ahumada, arcebispo do México, e Secretário-geral, Dom Alfonso López Trujillo, arcebispo coadjutor de Medellín (SOUZA, 2019, p. 71).
} 
Os temores do bispo brotavam de uma percepção realista das possibilidades políticas de realização da Conferência. Não obstante certos limites políticos, o staff Trujillo, de fato, se impôs com relativa eficiência com seus sujeitos e regras eclesiasticamente legítimos de condução dos trabalhos e desenhou uma nova dinâmica de funcionamento, diferente do que ocorrera na Conferência anterior. Frei Betto fala de três tendências principais que compuseram a assembleia, uma conservadora que com discurso eclesiástico prega a neutralidade política, outra ligada às pastorais populares, com solida formação teológica e convicta da renovação e uma terceira composta pela maioria que, disposta a aprender, vai construindo uma posição no processo da assembleia. (CHRISTO, 1979, p. 92-93).

Há que acrescentar ainda um componente determinante dos rumos da Conferência: os delegados que foram nomeados pela Cúria romana e a exclusão de nomes de participantes ligados à teologia da libertação, o que configura uma assembleia de fato episcopal. O historiador Enrique Dussel faz um balanço sintomático desse quadro:

Em Puebla havia 5,7\% de cardeais (contra 2,4\% em Medellín), 12,36\% de sacerdotes seculares (contra 16,465 em Medellín) e de religiosos somente 10,43\% (contra 13,25\% em Medellín). Em outras palavras, a composição era mais episcopal (em Medellín 55\% eram bispos, em Puebla 60\%), e, de maneira especial, os observadores protestantes passaram de 4,85 em Medellín a 1,35 em Puebla”. (DUSSEL, 1983, p. 577).

A III Conferência do episcopado se instalou como assembleia, de fato, episcopal com, pouco espaço para debates e para a contribuição de outros sujeitos eclesiais. O método de trabalho adotado teve como objetivo garantir uma hegemonia da participação e da palavra do episcopado, o que resultaria num exercício genuíno do magistério continental e em documento final coerente o suficiente para definir e corrigir os rumos das Igrejas locais. Ao menos do que oficialmente se intencionava com essa opção metodológica, a Conferência não significaria, portanto, o ponto de chegada um processo histórico-eclesial prévio, marcado por encontros, reflexões e elaborações textuais, de forma que a própria assembleia e o texto final fossem um saldo final, como havia acontecido na Conferência de Medellín e no próprio Vaticano II. A III Conferência foi construída 
diretamente em torno do texto confeccionado pelas Comissões sob a coordenação de bispos; ${ }^{2}$ esse método de trabalho visou controlar eventuais discussões que viessem ocorrer entre os participantes e o influxo de ideias de teólogos de plantão, concretamente os teólogos da libertação (COMBLIN, 1981, p. 99-102). Era uma opção metodológica consciente e deliberada que visava evitar, portanto, o método de Medellín, mas, antes de tudo, a reprodução do resultado de Medellín. O DP nasceu como uma nova fase de trabalhos que se iniciava, portanto, de um ponto zero, prescindindo das contribuições já elaboradas pelos documentos preparatórios, de modo particular o Documento de Trabalho (LIBANIO, 1982, p. 59)3. Diferentemente do método adotado por Medellín baseado na sequência, estudo-discussão-formulação-votação, que contava com a participação ativa dos assessores e dos sujeitos em plenário, Puebla centralizou os trabalhos nas Comissões e restringiu as possibilidades de discussão em plenário direcionando-se pela sequência esquema-redação-votação. É bem verdade que a assembleia refez o método originalmente apresentado sob a influência direta de Dom Luciano Mendes de Almeida, o que permitiu uma relativa porosidade nas Comissões de trabalho e uma composição plural que refletirá no texto final. (DUSSEL, 1983, p. 590-591).

Contudo, para além do método centralizador que controla os debates e os influxos teológicos externos, é necessário encontrar um ponto de equilíbrio analítico, considerar a "Puebla total", aquela que, de fato, foi possível de se realizar, tendo em vista as tendências eclesiais e teológicas presentes no seio da assembleia, expressão da vivência concreta das Igrejas espalhadas pelo continente e pleno processo de recepção do Vaticano II, via Conferência de Medellín (DUSSEL, 1981, p. 58-61). Em termos hermenêuticos, significa afirmar que DP opera seu significado dentro de um contexto, onde se localizam sujeitos e pressupostos que preparam o clima mais amplo da Conferência, penetram para dentro da mesma por meio de prelados e de subsídios oferecidos por teólogos e, sobretudo, constitui o

\footnotetext{
${ }^{2}$ Foram criadas 21 Comissões de trabalho que se dedicavam à elaboração do texto em torno de 4 núcleos básicos: Visão pastoral da realidade da América Latina, Reflexão doutrinal, Evangelização na e pela Igreja na América Latina, Igreja evangelizadora e missionária hoje e no futuro da América Latina (LIBÂNIO, 1982, p. 59-60; DUSSEL, 1983, p. 590-591).

${ }^{3}$ Uma exposição das expectativas sobre as contribuições do Documento de Trabalho para a III Conferência foi sistematizada por Alberto Antoniazzi, do Instituto Nacional de Pastoral. Ali apresentava como Pistas de ação: o primado do Evangelho, o primado da renovação, a opção pela libertação e pelos pobres e a mobilização de todos (ANTONIAZZI, 1978, p. 611-624).
} 
ambiente da recepção das decisões codificadas no DP. Emerge, desse modo, uma Conferência como evento eclesial que acontece inevitavelmente como processo feito de distintas temporalidades - ao menos três principais: o antes, o durante e o depois - que se extrapola para além dos controles metodológico-textuais como lugares de sentido. Há que relacionar Puebla com o contexto histórico-eclesial (a era do Vaticano II em que se encontra a Igreja e, de modo particular, no continente latino americano), com o processo que tem a III Conferência como epicentro (a fase preparatória com os dois documentos e os encontros preparatórios, a realização da Conferência e a fase de recepção) e com o estilo do documento final (documento resultado de consensos construídos naquela assembleia). O documento final, não obstante constituir uma objetividade textual de natureza normativa, enquanto texto do magistério local, se insere inevitavelmente em um contexto que o produz e, sobretudo, que o recepciona. 4 Nesse sentido, a intenção de rever e corrigir a Conferência de Medellín, explicitada por setores vigilantes da ortodoxia católica, ali representados por membros da Cúria romana, por setores do episcopado e pelo próprio Papa, teve um resultado relativo: mais textual que histórico. Foi, por fim, a recepção de Puebla que deu às suas orientações a medida real de aplicação e de interpretação.

Por essa razão, as hermenêuticas de Puebla podem ser variadas, como, de fato, ocorreu na fase de recepção do evento. Por certo, podem-se tipificar três hermenêuticas principais que se mostram presentes no processo de realização do evento: uma conservadora que recebe Puebla como momento de correção história dos rumos da Igreja latino-americana, caso típico da leitura feita por Boaventura Kloppenburg (1979), uma leitura libertadora, sendo a mais emblemática em nosso contexto as obras Diário de Puebla e Puebla para o povo de Frei Betto e, evidentemente, uma leitura episcopal, pautada pela busca de coerência na doutrina e nas orientações pastorais da Conferência, uma nítida hermenêutica da continuidade com a tradição anterior e do consenso eclesial. Essa recepção pode

\footnotetext{
${ }^{4}$ Há que ressaltar, portanto, uma distinção fundamental entre o texto (documento final), a III Conferência (a assembleia do episcopado), o contexto/processo eclesial que prepara a Conferência (encontros, documentos anteriores, reflexões etc.) e a fase de recepção (com suas lutas, sujeitos e estratégias). O sentido global de Puebla pressupõe essa totalidade e brota desse processo concreto, amplo e complexo, para além de uma leitura literal da objetividade textual do DP.
} 
ser detectada de modo claro nos Documentos da CNBB que foram sendo elaborados na década seguinte à Conferência. 5

Pode-se dizer que a ambiguidade conservação-renovação é constitutiva do evento Puebla como um todo. Com efeito, essas duas tendências se dispõem ao longo do documento com seus conceitos e se oferecem com seus conteúdos passíveis de serem destilados em tipos puros, a depender da opção de leitura. A Conferência de Puebla configura, nesse sentido, um testemunho histórico emblemático sobre o período de recepção do Vaticano II, com suas lutas hermenêuticas, quando eram dados os passos decisivos de uma releitura conservadora do processo de aggiornamento conciliar, sob a gestão estratégica do Papa João Paulo II. O páreo de Puebla foi, de fato, um marco decisivo do que se verificou nas décadas seguintes em termos de luta pelo sentido do Concílio no âmbito da Igreja católica, sendo a América Latina o canteiro fecundo de uma luta que chegou a conflitos abertos entre a Cúria romana e a Igreja local do continente. Este dado histórico não somente compõe de modo original a história da Igreja como laboratório de visões e de criações originais na era pós-conciliar, mas também explicita a tomada de posição profética da Igreja como um todo, do episcopado latino-americano e das Igrejas espalhadas pelo continente.

Puebla reproduz de modo próprio e no processo de sua recepção o que ocorreu no Vaticano II em termos metodológicos: não obstante a luta hermenêutica aí constitutiva, afirma um método legítimo de pensar a fé, ação que ocorre dentro da história e em relação com ela, ainda que se utilize de expedientes dogmáticos e metodológicos tradicionais (KÜNG, 1999, p. 130-133). A sensibilidade para com a história pode ser localizada como um pathos básico que garante a profecia da III Conferência, mesmo quando um logos conservador se impõe como doutrina

\footnotetext{
${ }^{5}$ Desde o conhecido Subsídio para Puebla, aprovado pelos bispos na assembleia de 1978, e que desembocará no Documento de Trabalho, mas, sobretudo, os Documentos que são aprovados após a Conferência. Exemplos de eco imediato: (CONFERÊNCIA NACIONAL DOS BISPOS DO BRASIL, 1980). O objetivo geral da ação pastoral foi assim formulado em 1979: "Evangelizar a sociedade brasileira em formação, a partir da opção pelos pobres, pela libertação integral do homem, numa crescente participação e comunhão, visando a construção de uma sociedade fraterna, anunciando assim o Reino definitivo". O Doc. 20 vincula esse objetivo diretam ente às orientações de Puebla. Ver Conferência Nacional dos Bispos do Brasil (1981).
} 
legítima, verdadeira e normativa da parte de uma ortodoxia vigilante na Conferência.

Em todo processo de recepção coloca-se a questão básica da relação entre o texto os sujeitos receptores; em termos técnicos, entre objetividade e subjetividade. No caso de textos resultados de Conferências ou de Sínodos que envolvem metodologias participativas preparatórias, como tem ocorrido nos Sínodos atuais, essa circularidade adquire um dinamismo próprio: o texto final e oficial se insere, inevitavelmente, em um processo mais amplo de construção de sentido que, em certa medida o produz, e, em boa medida, o recepciona. $\mathrm{O}$ texto não esgota, por si mesmo, todo sentido como uma objetividade acabada, mas, ao contrário, se insere em um contexto complexo de expectativas, de “verdades prévias" e de decodificações que constroem um sentido global para o seus resultados. O contexto eclesial latino-americano foi um fator decisivo para a construção do sentido de Puebla, ainda que o método da III Conferência tenha sido centrado na construção de uma objetividade textual. No caso, essa circularidade hermenêutica entre texto e sujeitos fica, de fato, condicionada a alguns fatores que constroem muito logo o significado hegemônico do texto na fase de recepção: a) o clima e a geração da era pós-conciliar aberta aos processos de renovação eclesial, que, de alguma forma, vincula a missão da Igreja à realidade presente e busca nessa dialética os rumos das reflexões e práticas eclesiais; b) a tradição consolidada de Medellín pelo continente afora, nas práticas pastorais, nas organizações eclesiais (as CEBs e as pastorais populares), na metodologia de leitura da Bíblia, nas reflexões teológicas e nos documentos eclesiais dos magistérios locais; c) nas urgências da realidade presente: as Igrejas da AL receberam Puebla em contextos de urgências sociais e políticas que clamam por posturas, discernimentos e decisões das Igrejas locais como saídas para os contextos de opressão; d) a atuação pedagógica de agentes eclesiais que afirmavam uma leitura de Puebla em consonância com Medellín e como resposta aos desafios presentes. 


\section{A luta estratégica pelo sentido teológico do Vaticano II}

A Conferência de Puebla posiciona-se no pós-concílio como marco revisor do processo de aggiornamento (ALMEIDA, 2015, p. 8-9) que construiu o Concílio Vaticano II no espírito e na letra. O que Massimo Faggioli designou como "luta pelo sentido" (2013) para compreender o processo conciliar se encontrava naquele contexto histórico em um momento de inflexão: o de retomar a tradição, a doutrina e a práxis eclesial segundo um parâmetro que permitisse corrigir os erros em curso no interior da Igreja. Segundo essa visão, o Vaticano II, concluído havia mais de uma década, mostrara seus limites e contava, então, com um novo Papa disposto a conduzir uma orientação clara e segura a respeito das reformas conciliares. A maioria conciliar que havia decidido as orientações básicas do Concílio já não estava investida do vigor original das reformas, bem como, distante do carisma renovador, se realinhara em diferentes tendências, incluindo aquela que pretendia rever os rumos do aggiornamento. O momento primordial de consenso dera lugar a dúvidas e dissensos sobre o que, de fato, havia pretendido o Concílio. A América Latina fora, de fato, o canteiro fecundo da recepção conciliar onde se mostrava visível a pretendida renovação da Igreja: expressão mais autêntica das orientações conciliares para muitos, expressão dos equívocos da renovação para outros. A Conferência de Medellín havia colocado o Concílio em prática e tirado as consequências radicais de suas decisões. Uma década mais tarde a Igreja não era mais a mesma. A Cúria Romana, caudatária institucional e direta dos pouco entusiastas de renovação e, até mesmo, da chamada minoria conciliar, se tornara mais empoderada pelos setores tradicionalistas da Igreja, sabendo que, desde a conclusão do grande Sínodo, Dicastérios e prelados curialistas se dedicavam sempre mais a institucionalizar as reformas em moldes conservadores e o Papa Paulo VI se tornara também mais frágil e refém dos mesmos segmentos. O que no processo conciliar havia sido abafado como posição secundária, em termos de visão e prática eclesial, vai assumindo progressivamente um protagonismo visível e eficiente. A própria dinâmica pós-conciliar que entregara o Concílio a todo o povo de Deus para que fosse aplicado, não contava com um mecanismo 
institucionalizador do aggiornamento; ao contrário, as renovações estavam delegadas às decisões das Igrejas locais e, por conseguinte, ao jogo de forças das convicções teológicas e decisões pastorais localizadas.

A eleição do Papa polonês introduzia uma variável decisiva nos rumos revisores do Concílio. Como bem intuiu João Batista Libanio (1984), tratava-se de um projeto de "volta à grande disciplina" nos moldes anteriores ao Vaticano II (LIBÂNIO, 1984). A III Conferência era a oportunidade de corrigir os erros e dar um passo à frente; momento estratégico que permitia ao novo Pontífice expor sua posição em relação ao que se passou na América Latina desde Medellín e capitanear um projeto novo para toda a Igreja. No discurso inaugural pronunciado no Seminário Palafoxiano o Papa deixa clara essa posição:

\begin{abstract}
Nesses dez anos, quanto caminhou a humanidade e com a humanidade e a seu serviço, quanto caminhou a Igreja! Esta III Conferência não pode desconhecer essa realidade. Deverá, pois, tomar como ponto de partida as conclusões de Medellín, com tudo o que tem de positivo, mas sem ignorar as incorretas interpretações por vezes feitas e que exigem sereno discernimento, oportuna crítica e claras tomadas de posição. (Conclusões de Puebla, p. 14).
\end{abstract}

De outra parte, os resultados do aggiornamento conciliar mostravam seus frutos visíveis nas Igrejas da América Latina. Após o Concílio florescera como seu resultado fiel e coerente expressões eclesiais locais: a reflexão teológica, a colegialidade, as pastorais e ministérios, a presença profética da Igreja e o serviço aos pobres. Para os sujeitos eclesiais, bispos, presbíteros, religiosos e leigos, que protagonizavam esse processo a América Latina representava o espaço e o tempo da fiel renovação da Igreja. Dom Aloísio Lorscheider falava em seu discurso de abertura em "vitalidade nova" das Igrejas do continente manifesta na oração, na colegialidade, nas comunidades eclesiais de base, nos novos ministérios, na inserção eclesial nas áreas pobres, na planificação e participação pastoral, na metodologia de análise de realidade, na consciência dos leigos e na identidade eclesial (Discurso de Dom Aloísio Lorscheider. Conclusões de Puebla, p. 45-50). Essa era, sem dúvidas, a herança direta do Concílio e de Medellín recolhida como tradição a ser levada adiante naquela Conferência que se iniciava. 
Há um substrato bem evidente da teologia da libertação nesse discurso inaugural do Cardeal presidente do CELAM. Vale recordar que entre os peritos presentes na III Conferência não constou nenhum teólogo representante dessa corrente teológica, embora fosse uma expressiva elaboração da era pós-conciliar no continente e houvesse dado o tom da Conferência anterior. De fato, as teses da teologia da libertação com seus teólogos eram, naquele momento, o inimigo visível a ser combatido na Igreja da América Latina, embora essa luta hermenêutica deva ser inserida no contexto mais amplo das teologias conciliares.

Sem dúvida, tratava-se de um conflito aparentemente novo. A luta travada no interior do Vaticano II assumia agora enfrentamentos concretos, numa relação assimétrica de dupla mão. Por um lado, do ponto de vista da legitimidade eclesial, tratava-se de uma batalha perdida em médio prazo para a teologia e as Igrejas locais, tendo em vista o ethos católico da tradição e da fidelidade ao Magistério papal que ali se instala como portador do discurso legítimo e da ortodoxia da fé. Porém, de outra parte uma tradição eclesial local se encontrava consolidada, como bem expressava Dom Aloísio em seu discurso. Uma leva crescente de teólogos jovens e produtivos assumia o protagonismo da reflexão no continente e a frente eclesial libertadora configurava práticas e imaginários consolidados pelo continente afora que, de fato, só seriam alterados com o passar do tempo e sob as estratégias centralizadoras da Cúria romana. A luta pelo sentido do Vaticano II analisada por Faggioli oferece uma chave de compreensão de alcance mais amplo sobre o que se encontrava em jogo naquele momento. O processo conciliar já se dera em uma dialética que opunha não somente os representantes conservadores da chamada minoria conciliar com os adeptos da renovação, mas também duas tendências teológicas distintas: os agostinianos e os tomistas (FAGGIOLI, 2013, p. 102-131). Para além dessa tipificação, o que realmente se apresentava como perspectivas distintas na hermenêutica conciliar era uma leitura nos termos da velha tradição teológica de raiz platônica e essencialista e outra nos termos da tradição tomista, aberta à incorporação da história como grandeza positiva nas considerações sobre o mundo moderno. Essa dialética ressoa na III Conferência 
com nitidez, com sujeitos, conteúdos e espaços definidos. Duas teologias estão no comando das reflexões, embora o protagonismo dos bispos e da própria Cúria romana permite perceber uma hegemonia da teologia clássica de viés agostiniano que insiste em partir sempre dos princípios doutrinais para se considerar os desafios da realidade. No mesmo processo, muitos bispos e o próprio presidente do CELAM pensam a partir das referências da teologia latino-americana, centrada na história, no discernimento e na ação pastoral.

A fase preparatória da Conferência retrata essas distintas hermenêuticas, no vai e vem dos textos e dos encontros. A ruptura deliberada da assembleia da III Conferência com os Documentos de Consulta e de Trabalho, visara, sem dúvidas, produzir uma reflexão autenticamente episcopal e sob seguro controle teológico. De fato, nesse controle, a doutrina tradicional tem um lugar geral e estruturante no conjunto do Documento final. Para tanto, o Discurso de João Paulo II teve uma função performativa, seja na anunciada necessidade de se reler a tradição de Medellín, seja na formulação das três verdades a serem ensinadas pelos bispos: as verdades sobre Jesus Cristo, a Igreja e o homem. A categoria "verdade" adotada pelo Papa sinalizava claramente para a necessidade de distinguir o verdadeiro do falso, presentes na práxis e na reflexão da Igreja latino-americana. Uma verdade transmitida pela tradição e magistério da Igreja se apresentava como acervo disponível e parâmetro normativo de discernimento das renovações em curso na América Latina. E como bem observou João Batista Libanio, esse discurso teve um impacto sem precedentes na assembleia, superando as fontes clássicas da teologia em número de referência. Assim diz Libanio na introdução didática do DP das Edições Loyola:

Assim João Paulo II com uma semana de discursos vai impressionar mais os redatores do documento, que uma longa tradição eclesial. Isto mostra que não se atém tanto aos documentos por causa de seu valor teológico interno, segundo a criteriologia da própria Igreja, mas antes por causa da força psicológica (e também ideológica) deles. (LIBANIO, 1982, p. 66). 
E conclui com uma crítica severa:

Todos sabemos que um discurso de um Papa numa viagem tem muito menos importância teológica que os ensinamentos dos Santos Padres, dos grandes Concílios, das Encíclicas. E, apesar disso, eles foram citados no Documento de Puebla mais de 100 vezes [...]. (LIBANIO, 1982, p. 66).

A assembleia de III conferência se encaminhará com uma metodologia de controle teológico que visa rever e avaliar a tradição de Medellín, filtrar os eventuais influxos da teologia da libertação, dispensar o trabalho desses teólogos, minimizar as influências de assessores e produzir um documento autenticamente episcopal. Contudo, dois fatores vão de encontro com esse controle central: a presença de bispos convictos da verdade da renovação conciliar consubstanciada em Medellín e a pressão externa do contexto histórico continental que clama por uma palavra de discernimento da Igreja ali presente e por solidariedade efetiva dos cristãos com os processos de desumanização. Esses dois fatores, pode-se dizer, quebram mais no fundo que na forma uma eventual unanimidade tradicionalista que viesse efetivamente reger a teologia e a pastoral do DP. Nesse sentido, pode-se falar na reprodução tardia daquela luta conciliar: de uma tendência centrada numa visão essencialista da realidade, amparada e reproduzida por esquemas lógicos e doutrinais do agostinianismo e uma tendência que advém diretamente da teologia conciliar de cunho histórico, cujo princípio e método se expressavam na categoria sinais dos tempos, praticada e oferecida pelo mesmo Concílio.

Portanto, do ponto de vista metodológico, pode-se inferir duas tendências que se cruzam na estrutura de fundo do Documento; são duas perspectivas teológicas com suas metodologias decorrentes: o esquema clássico de matriz agostiniana centrado na tríade criação-queda-redenção com suas aplicações pela via da dedução e o esquema moderno subjacente ao método indutivo ver-julgaragir tipificado na dialética teológica: história-revelação-discernimento-ação. $\mathrm{O}$ primeiro esquema oferece os princípios a partir dos quais se pensa a realidade presente e se assume uma postura perante ela; o segundo parte da ambiguidade da realidade, ambiguidade a ser discernida pela Palavra que fala no tempo atual e se 
busca como resultado uma determinada decisão e ação. O primeiro oferece uma verdade construída que deve ser aplicada universalmente em toda e qualquer realidade. O segundo acolhe a história como lugar da revelação de Deus e se busca discernir no seu interior o plano de Deus, mediante os parâmetros bíblicos. O primeiro se reproduz, dedutiva e autoritariamente, de um sistema doutrinal centrado $\mathrm{n}$ a tradição e magistério, concretamente no magistério papal. O segundo opera como confronto entre tradição/magistério e realidade, mas, antes, entre as Escrituras e a realidade histórica.

O DP opera com essas duas perspectivas e métodos no conjunto e nas partes. A teologia clássica estrutura como que oficialmente o momento do Julgar como garantia de uma ortodoxia da fé perante os riscos desvios teológicos enumerados em várias passagens. ${ }^{6}$ A teologia da história fornece o esquema geral do Documento, espécie de pressuposto geral que enquadra o conjunto da reflexão no vínculo permanente entre conteúdos da fé e conteúdos da realidade. Os cruzamentos dos dois esquemas são visíveis. Na segunda parte, ocorre uma espécie de atualização da teologia clássica que vai sendo ancorada à realidade, explicitando - inevitavelmente - os lugares comuns da teologia da libertação. Nas demais partes, assume a postura de correção do que entende ser desvios da mesma teologia. Em algumas passagens podem ser também surpreendidas sínteses menores que articulam os dois modelos teológicos. O DP expressa, assim, um processo históricoeclesial concreto sendo pensado e conduzido por tendências teológicas em busca de legitimidade como fieis à tradição e iluminadoras das urgências apresentadas pelo contexto da época. Com efeito, a tendência histórica expressa na sensibilidade para com as urgências do contexto concreto e em um método que necessita ancorar de alguma forma o doutrinal no histórico, perpassa o DP como preocupação de fundo que legitima a reflexão nas três partes. Como bem expressa Gomes de Souza, um texto de natureza pastoral não se constrói por via negativa (como no caso dos documentos de natureza jurídica), mas, por via positiva, o que fez com que as

\footnotetext{
${ }^{6}$ Além das correções cristológicas $(176,178,179,1166)$, eclesiológicas (222, 223, 262 e 263) e antropológicas (308-315), podem ser observadas também correções referentes à teologia da salvação $(353,354)$ e, sobretudo, nos reparos ao conceito de libertação $(26$, $141,189,321,475,480,481,482,488,489696,895,1026,1134)$ e, de modo enfático, no método teológico que faz uso da análise marxista (91, 544 e 545).
} 
tendências políticas e teológicas mais proativas e avançadas tenham conseguido impor suas perspectivas no conjunto das deliberações (SOUZA, 1979, p. 68). O contexto histórico acolhido como dado concreto, discernido pela fé e assumido como desafio para a ação urgente da Igreja salvou a III Conferência da reprodução homogênea e hegemônica da tradição teológica clássica ali presente como ortodoxia vigilante e sanadora de equívocos.

\section{As recepções e a recepção de Puebla}

Como já foi acima mencionado, é possível distinguir recepções distintas de Puebla e afirmar a relevância desse momento do evento eclesial Puebla para a compreensão de seus resultados. Os tipos apresentados podem ser verificados em textos que se tornaram conhecidos logo em seguida à Conferência. Os sujeitos ali presentes foram também sujeitos que construíram, cada qual segundo suas perspectivas, recepções do DP. Vale verificar rapidamente duas posturas principais.

Boaventura Kloppenburg não esconde as intenções revisoras do Documento no seu Artigo supracitado:

[...] el documento debe dar una doctrina clara sobre Cristo, explícita e inequívoca; que de hecho en América Latina existen actualmente diversas cristologías que no satisfacen los requerimientos de la fe cristiana bíblica y tradicional; [...] También sobre la iglesia hubo varias intervenciones: que urge deshacer sin ambages los equívocos existentes sobre la naturaleza y misión de la Iglesia, que el Documento debe rechazar categóricamente aquellas tesis que propugnan una visión de la Iglesia contraria a la que nos da la Tradición y sobre todo el Concilio Vaticano II; que es necesario denunciar, como lo hizo el Papa Juan Pablo II, la llamada 'Iglesia popular' que pretende poner la dirección de la Iglesia, su doctrina y su liturgia, en la base. (KLOPPENBURG, 1979, p. 200-201 ).

As divergências internas da Conferência de Puebla, retratadas no Diário de Puebla, de Frei Betto, bem como pelo historiador Enrique Dussel (1983), se mostram visíveis no subtexto do Documento final. Contudo, não aparecem na fase da recepção, quando, de fato, uma hermenêutica da continuidade de Medellín se fez unânime pelo continente afora. Nesse aspecto, o texto popular de Frei Betto, Puebla para o povo, se mostra emblemático. A III Conferência é traduzida em 
linguagem popular e não obstante o esforço de fidelidade ao texto, deixa nítida a leitura feita na perspectiva da teologia da libertação e das Comunidades Eclesiais de Base. Vale transcrever o inicio da Introdução que visa definir o que foi a Conferência:

Esta é uma versão popular do Documento de Puebla. Este documento é fruto de um mutirão de cerca de 356 pessoas - leigos (índios, camponeses, operários, casais), religiosos, padres bispos e cardeais. Toda essa gente esteve reunida na cidade de Puebla, no México, de 27 de janeiro da 13 de fevereiro de 1979 [...] Representavam a Igreja católica em nosso continente [...]. (BETTO, 1979, p. 7).

O livro popular do dominicano com suas sucessivas edições emblematiza a recepção libertadora de Puebla, amplamente praticada nos grupos e pastorais populares pelo continente afora. A organização pastoral das Igrejas, segundo as orientações de Medellín e a reflexão teológica latino-americana instauravam, de fato, um clima amplamente favorável a uma recepção de Puebla na linha de um documento que vinha para oferecer um caminho de libertação para os povos do continente. Logo após a Conferência, Enrique Dussel propunha exatamente uma recepção popular como estratégia que poderia superar a pretendida ruptura com a tradição e Medellín. Por essa razão insistia ser: “a 'apropriação' popular de Puebla é a tarefa atual e imediata" (DUSSEL, 1981, p. 60).

Enquanto a leitura apresentada por Kloppenburg, embora revestida de autoridade teórica e política, por tratar-se de um teólogo perito da Conferência e que fala em nome da própria coordenação da mesma (ao menos de uma ala da coordenação), ficou restrita ao âmbito dos debates teóricos de uma elite eclesial, teológica e pastoral7, a leitura que predominou pelo continente firmou-se na perspectiva da continuidade da tradição de Medellín em sintonia com o que programava Dussel. É nessa mesma direção que Leonardo Boff fazia um balanço da Conferência em termos de "ganhos, avanços e questões emergentes" e definia esse avanço, não tanto para frente, mas para os lados como "alargamento de consenso eclesial" e como um "momento do Espírito na história de nossa Igreja" (BOFF,

${ }^{7}$ Caso das posturas do então secretário do CELAM; conferir Trujillo (1982). 
1979, p. 44). No mesmo artigo o teólogo detecta 10 eixos positivos que atravessam o texto conclusivo: consagração do método ver-julgar-agir, dimensão social e política da fé, defesa e promoção da dignidade da pessoa humana, opção preferencial pelos pobres, promoção e libertação integral, religiosidade popular, Comunidades Eclesiais de Base, opção preferencial pelos jovens, promoção da mulher e três condenações (as idolatrias da riqueza na forma do capital e do coletivismo marxista e a ideologia de segurança nacional). Conclui esse elenco positivo afirmando que Puebla "se constitui numa vigorosa reafirmação do caminho da Igreja nos últimos 10 anos." (BOFF, 1979, p. 51-52).

De fato, a ambiguidade conservação-renovação é constitutiva em Puebla, quando não dos documentos eclesiais de um modo geral. As duas tendências se dispõem ao longo do documento com seus conceitos e se oferecem com seus conteúdos passíveis de serem destilados em tipos puros, a depender da opção de leitura.

Vale lembrar que toda recepção é antes de tudo um processo; envolve leituras, sujeitos, contextos e opções distintas, sempre na busca de uma fidelidade coerente e ativa de uma orientação eclesial. Portanto, não se trata nem de uma aplicação mecânica e nem de uma leitura traidora das orientações. A aplicação mecânica evoca o método do decreto que começa e termina na lei e nem sempre gera convicção e vida na comunidade eclesial e em cada fiel. A leitura traidora, por natureza dissimulada, esconde sutilmente os interesses alheios ou até mesmo contrários às orientações; esse tipo de recepção tem sido recorrente no pontificado atual. Uma recepção envolve, portanto processo de acolhida de uma orientação ou norma e estratégias de compreensão de conteúdos e de construção de ações comuns. A recepção exige, portanto, tempo de trabalho, pressupõe a ação de sujeitos, e construção de consensos interpretativos e de ações conjuntas. (PASSOS, 2018, p. 284). 
A recepção de Puebla se deu antes de tudo em um contexto, por meio de sujeitos e de uma metodologia demarcados pela tradição de Medellín, em uma cultura eclesial que lê a realidade e compreende a Igreja e sua missão segundo as orientações de Medellín. Nesse sentido a circularidade entre a segunda e a terceira conferência aconteceu de fato: como ação consciente ou espontânea. Houve, nesse sentido, uma hermenêutica da continuidade entre os dois eventos. As forças eclesiais ativas e portadoras dos carismas renovadores do Concílio e de Medellín fizeram uma recepção renovadora dos ensinamentos de Puebla, superando aquelas contradições internas do Documento e, sobretudo, as que marcaram a assembleia, como testemunham os que ali estiveram presentes e ausentes.

A III Conferência levou adiante a era conciliar, explicitando a consciência histórica da Igreja (THEOBALD, 2015, p. 122-202) naquela hora urgente dos povos latino-americanos. A leitura dos sinais dos tempos se fez de modo concreto e não somente como postura ética ou hermenêutica perante a realidade. A realidade do continente foi discernida em suas estruturas e causas e a Igreja assume posicionamento profético que exige mudança de comportamento por parte dos sujeitos religiosos e opção pelos pobres e sofredores. Essa postura tem sua tradução social e política, o que encarna o Vaticano II no tempo e no espaço do povo de Deus. No processo de recepção de Puebla foi efetivado a partir de um senso de fé e de um método teológico que articularam de modo intenso, crítico e criativo fé e vida, igreja e realidade, práxis sacramental e práxis política.

\section{Considerações finais}

Os fios da história teceram com seus apelos concretos a trama de Puebla forneceram o clima eclesial que garantiu uma hermenêutica capaz de articular Medellín com Puebla e, por conseguinte, essa com os contextos eclesiais de então. O contexto histórico e a práxis pastoral forneceram a base para a recepção libertadora de Puebla e pode fornecer também hoje o eixo que constrói uma continuidade sobre os eixos básicos da opção pelos pobres, da Igreja servidora e da luta pela justiça. O evento Puebla se eleva como momento de consciência da 
realidade de opressão e da missão profética da Igreja. Essa perspectiva e esse valor mostram sua atualidade, na medida em que a pobreza persiste no continente e se torna mundializada e que tendências politicas autoritárias se expandem pelo continente e pelo mundo. A conjuntura histórica que provocou e possibilitou a III Conferência, mostra hoje seus desdobramentos tardios, senão suas regurgitações ainda mais perversas: mecanismos geradores de pobreza mundializados pela era do mercado financeiro improdutivo, idolatrias do mercado e do dinheiro, alienações produzidas e reproduzidas pela cultura de consumo, negação de direitos sociais e de direitos humanos etc. A volta aos ensinamentos de Puebla torna-se necessária e urgente como fonte de onde se retiram princípios de discernimentos e critérios de ação para a vida e a ação dos cristãos.

A teologia de/em Puebla se insere em uma conjuntura eclesial que está marcada por uma luta hermenêutica mais ampla entre preservação e renovação, luta que envolve distintos sujeitos: prelados da Cúria e o próprio Papa e prelados da AL, teólogos de perfil conservador e teólogos da renovação (de modo particular os teólogos da libertação), clero e leigos. As matrizes teológicas disponíveis são assimétricas: a teologia dita oficial se apresenta como sinônima de ortodoxia da fé e de sã doutrina e se impõe pelo peso da tradição e pela força da oficialidade, enquanto da teologia renovada que brota do Vaticano II se impõe como resposta coerente e direta aos desafios urgentes da realidade. Na verdade, a assembleia não tinha como dispensar nenhum dos dois modelos, não obstante operem, muitas vezes, em nítido paralelismo. No final da batalha, pode-se dizer, que, não obstante um esquema teológico geral pautado pela matriz clássica, a teologia renovada e libertadora cumpriu sua função de conexão da doutrina com a realidade; funcionou como fio-terra da reflexão, como âncora da doutrina, mesmo nas suas formulações mais gerias e universais.

Vale lembrar que na fase de recepção a teologia latino-americana avança quantitativa e qualitativamente em sua reflexão, juntamente com as posturas proféticas dos episcopados, as comunidades de base e as pastorais sociais. O DP foi 
uma fonte eclesial fecunda para essas práticas e reflexões, consolidando a perspectiva de renovação eclesial desencadeada pelo Vaticano II e consolidada em Medellín. Puebla foi recepcionada e interpretada como um marco eclesial confirmador das renovações em curso no continente, não obstante os intentos de revisão programados pelas tendências eclesiais conservadoras. Evidentemente, na década seguinte avançou com mais força os mecanismos revisores desses marcos eclesiais e os controles diretos sobre o episcopado e a teologia produzida no continente da parte dos dirigentes de Dicastérios da Cúria romana.

Nos dias atuais, os ensinamentos do Papa Francisco permitem afirmar que o ensinamento fundamental da III Conferência permanece vivo e se universaliza, na medida em que Francisco possibilita uma volta ao essencial que vem do Evangelho e do clamor dos pobres, dimensões da mesma verdade da Palavra encarnada. Com Francisco, Puebla emerge como ensinamento autêntico do magistério local e universal e como evento que compõe legitimamente a história da teologia cristã-católica.

\section{REFERÊNCIAS}

ALMEIDA, A. José. Aggiornamento. In: PASSOS, J. Décio; SANCHEZ, Wagner L (org.). Dicionário do Concílio Vaticano II. São Paulo: Paulus: Paulinas, 2015.

ANTONIAZZI, Alberto. Observações e contribuições para Puebla. Revista Eclesiástica Brasileira, Petrópolis, v. 38, n. 152, 1978.

BOFF, Leonardo. Puebla: ganhos, avanços, questões emergentes. Revista Eclesiástica Brasileira, Petrópolis, v. 39, n. 153, 1979.

CASALDÁlIGA, Pedro. Visão da Igreja a partir da periferia. Revista Eclesiástica Brasileira, Petrópolis, v. 38, n. 152, 1978.

CHRISTO, Alberto Libanio. Tensões políticas e Puebla. Revista Eclesiástica Brasileira, Petrópolis, v. 39, n. 153, 1979.

COMBLIN, José. La conferencia episcopal de Puebla. In: EQUIPO SELADOC. Panorama de la teología latino-americana: Puebla. Salamanca: Sígueme, 1981. p. 91-104. 
CONFERÊNCIA NACIONAL DOS BISPOS DO BRASIL. $5^{\mathbf{0}}$ plano bienal dos organismos nacionais: 1978/1980. São Paulo: Paulinas, 1980.

CONFERENNCIA NACIONAL DOS BISPOS DO BRASIL. Vida e ministério do presbítero: pastoral vocacional. São Paulo: Paulinas, 1981. (Documentos da CNBB, 20).

DUSSEL, Enrique. De Medellín a Puebla: uma década de sangue e esperança. São Paulo: Loyola, 1983. v. 3.

DUSSEL, Enrique. La iglesia latinoamericana de Medellín a Puebla. In: EQUIPO SELADOC. Panorama de la teología latino-americana: Puebla. Salamanca: Sígueme, 1981. p. 13-61.

FAGGIOLI, Massimo. Vaticano II: a luta pelo sentido. São Paulo: Paulinas, 2013.

FREI BETTO. Puebla para o povo. Petrópolis: Vozes, 1979.

FREI BETTO. Diário de Puebla. Rio de Janeiro: Civilização Brasileira, 1979.

III CONFERÊNCIA GERAL DO EPISCOPADO LATINO-AMERICANO. Conclusões de Puebla. São Paulo: Loyola, 1982.

KLOPPENBURG, B. Génesis del Documento de Puebla. Revista Medellín, Bogotá, v. 5, n. 17-18, p. 190-207, enero./jun. 1979.

KÜNG, Hans. Teologia a caminho: fundamentação para o dialogo ecumênico. São Paulo: Paulinas, 1999.

LIBANIO, J. Batista. Introdução. In: III CONFERÊNCIA GERAL DO EPISCOPADO LATINO-AMERICANO. Conclusões de Puebla. São Paulo: Loyola, 1982.

LIBANIO, J. Batista. Volta à grande disciplina. São Paulo: Loyola, 1984.

PASSOS, J. Décio. As reformas da Igreja católica: posturas e processos de uma mudança em curso. Petrópolis: Vozes, 2018.

SOUZA, Luiz Alberto. Documentos de Puebla: diagnóstico a partir dos pobres. Revista Eclesiástica Brasileira, Petrópolis, v. 39, n. 153, 1979.

SOUZA, Ney de; SBARDELOTTI, Emerson (org.). Puebla: Igreja na América Latina e no caribe. Petrópolis: Vozes, 2019.

THEOBALD, Christoph. A recepção do Concílio Vaticano II. São Leopoldo: Unisinos, 2015. v. 1.

TRUJILlO, Alfonso Lopez. Opções e interpretações à luz de Puebla. São Paulo: Loyola, 1982. 